\title{
Labyrinthin, The Tumor Marker Recognized By MCA 44-3A6: A Case For Pan-Tumor Markers As Targets To Treat Cancer
}

This article was published in the following Dove Press journal: OncoTargets and Therapy

\section{James A Radosevich (1) Michael Babich (iD}

LabyRx Immunologic Therapeutics (USA) Limited, Sacramento, California, USA
Correspondence: James A Radosevich 1009 Johnson Ct, Belvidere, IL 61008 Tel +I 5303305888

Email jrados@labyrx.com

\begin{abstract}
A paradigm shift is currently underway on the relationship between cancer treatment markers and therapies. Labyrinthin is a prime example of such a marker because it is a pan-cancer target for adenocarcinomas. This movement supports the idea that we must change our thinking from various cancer types (eg, lung, breast, colon) to "cancer arising" in a given tissue or organ. In doing so, this would further support the efforts toward pantreatments rather than organ-specific treatments.
\end{abstract}

Keywords: labyrinthin, MCA 44-3A6 antibody, cancer marker, cancer target, pan-cancer, pan-tumor, biomarkers, cancer diagnosis, adenocarcinoma

\section{Background}

Carcinoembryonic antigen (CEA) was first reported by Gold and Freedman in 1965 and, like many tumor markers, has been extensively studied. ${ }^{1}$ For decades, the quest in the tumor marker world was to find targets that were specific for various organs; this was in part because physicians were trained to be specialists with select organs or organ systems. Oncologists not only specialized in treating patients with cancer, but also within select organs in the body. The pursuit of organ-specific markers followed this same path with the advent of immunological and molecular methods to define tumor types. Untold numbers of potential tumor markers have likely been dismissed as not being valuable because they are expressed by a number of tumors arising in a host of tissues. Such is the case of the antigen labyrinthin, recognized by the mouse monoclonal antibody MCA 44-3A6.

In the early $1980 \mathrm{~s}$, Radosevich et $\mathrm{al}^{2,3}$ set out to define tumor markers that were consistently expressed by a given pathological type arising in tissues throughout the human body. This approach was plagued by the fact that tumors had to be defined by pathologists and require exquisite attention to detail at the microscopic level (beyond that, some tumors did not display features that were detectable at the cellular level by microscopic techniques). This required the sorting of tumors using pathological methods, followed by the detection of molecular markers. The tumor set was then resorted, and a determination made as to whether the molecular marker did a better job of grouping tumors than did the initial sorting by traditional pathological methods (selective response to treatments, clinical outcomes, etc.). Using this approach, Radosevich et $\mathrm{al}^{2-4}$ could consistently define a group of lung tumors as being adenocarcinomas and not other tumor types found in the lung that looked like adenocarcinomas. 


\section{MCA 44-3A6 Antigen (Labyrinthin) In An Evolving View Of Pan-Cancer Targets}

As additional studies confirmed the presence of labyrinthin in lung adenocarcinomas, ${ }^{5,6}$ the question arose whether labyrinthin, the antigen recognized by MCA 44-3A6, could be equally consistent in sorting adenocarcinomas from other tumor types arising in other tissues. Indeed, MCA 44-3A6 recognized labyrinthin on breast, ${ }^{7}$ bronchial tract, stomach, small intestine, pancreas and colon in cancer tissues derived from adults; ${ }^{8,9}$ the aerodigestive tract, exocrine pancreas, neural tissues, renal tubules, and transitional urothelium during human fetal development; ${ }^{10}$ and more recently labyrinthin has been found to be selectively associated with adenocarcinomas from a variety of cancer cells and tissues (eg, NCI-60 human tumor cell line panel; data not shown). Thus, it turns out that labyrinthin serves as a pan-adenocarcinoma marker regardless of the organ system. At the time, however, labyrinthin could have easily been dismissed as having little to no value as a tumor marker because it is not organ-specific.

Consider the case of antibiotics in medicine. After the dawn of antibiotic use, eventually came the wide use of sensitivity testing. Empirical testing on the patient at hand was done to jump-start the control of the infection, but sensitivity testing focused the aim on the antibiotic(s) to be used. In every case, it is the sensitivity of the infectious agent, not the location of the infection in the body that directs antibiotic selection. There are different formulations of antibiotics to optimize the delivery of the drug (to the eyes, ears, GI tract, etc.), but the sensitivity of the microbe is still the driving force for the antibiotic drug selection. Why then not do the same for cancer treatment?
In the case of the Her2/neu tumor marker/target for breast cancer, the FDA approved (1998) Herceptin, the anti-HER2 antibody for breast cancer. However, because our understanding of HER2/neu evolved, Herceptin is now approved for gastric cancer (2010), and several other therapeutic targets appear on the horizon such as ovarian, salivary, uterine, and even some lung cancers.

With respect to labyrinthin, several studies have shown that it is a pan-adenocarcinoma marker because it is selectively located on the cell surface of adenocarcinomas and not normal cells nor other cancers. For example, Figure 1 shows that both the MCA 44-3A6 antibody and an MCA 44-3A6-derived humanized antibody fragment ${ }^{11}$ react with human lung adenocarcinoma cells. These and other data from numerous human tissues and cell lines; ${ }^{3}$ (references therein and as described earlier) collectively support the idea that labyrinthin is a convenient, specific adenocarcinoma diagnostic and therapeutic pan-tumor target.

\section{Pan-Cancer Marker Effects On Cancer Diagnostic And Therapeutic Perspectives}

Considering the Her2/neu and labyrinthin examples, it is proposed herein that rather than using labels such as "breast cancer", "colon cancer", "prostate cancer", etc., a new reference point be adopted. If we take the perspective of cancer "arising in the breast", "arising in the colon", or "arising in the prostate", then we are more apt to address the commonalities between various tumors and recognize the fact that there can be many more commonalities among tumors arising in various tissues than there are differences.

Acceptance of this paradigm shift will open funding and policy opportunities to truly advance our understanding of

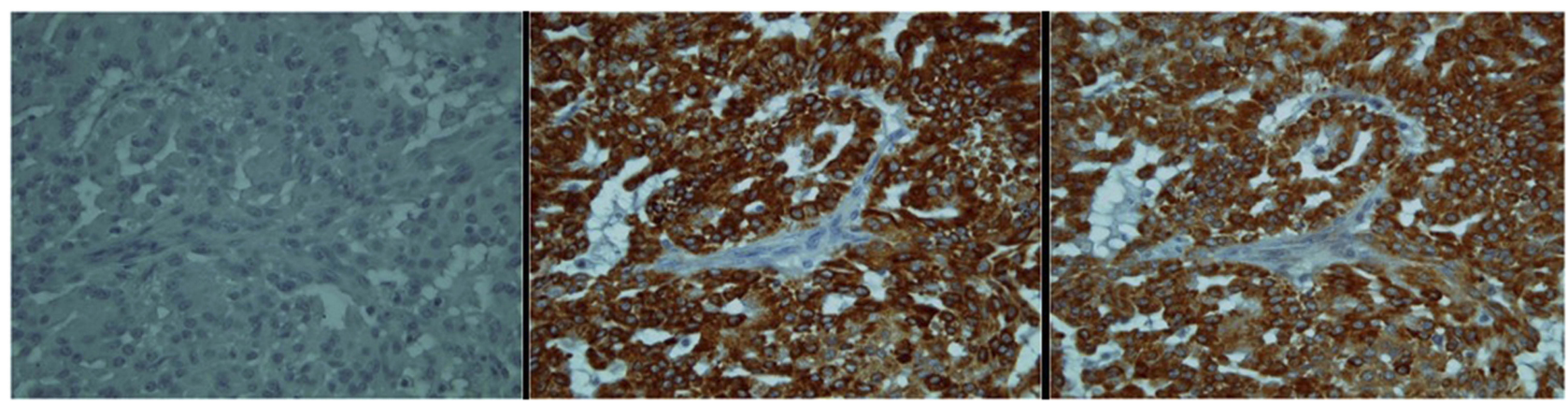

Figure I Photo micrographs of antibody interaction with lung adenocarcinoma cells.

Notes: Xenografts of A549 human lung adenocarcinoma cells grown in mice; magnification 400x. Left panel: background; secondary antibody alone. Middle panel: MCA443A6 antibody. Right panel: Humanized Fab. Normal fibroblasts and other cells that infiltrated the tumor mass do not immunostain (middle and right panels). 
cancers as well as allowing new treatments to become "board use" treatments early on in a treatment development. For instance, because prostate and breast cancer tumors express labyrinthin, research funding and efforts into those cancer types could complement each other. Consequently, treatments can be developed such as synthetic peptide vaccines or antibodies against labyrinthin to benefit patients with adenocarcinomas arising anywhere in their bodies, including any metastatic disease.

\section{Conclusion}

Although a need for tissue-specific markers to help locate tumors either in a given tissue or of an unknown origin remains, it is likely that numerous markers have been dismissed as useless because they are not tissue-specific. Conceivably, those markers could have joined the ranks of pan-tumor targets for developing treatments. Fortunately, modern immunotherapy has enlightened our thinking of cancer etiology. As a result, recent strides in research have been made to identify pan-tumor markers, often from a genetic standpoint. ${ }^{12-17}$ The discovery and elucidation of more convenient targets, such as the labyrinthin protein expressed on adenocarcinoma cell surfaces, will contribute greatly to the future of cancer diagnosis and treatments.

\section{Disclosure}

Professor James A Radosevich reports grants from National Institutes of Health and the Veterans Affairs Research, he is a consultant for LabyRx, Inc. Dr Michael Babich reports A Small Business Innovative Research grant from the National Institutes of Health and he is a consultant for LabyRx Immunologic Therapeutics Limited. The authors report no other conflicts of interest in this work.

\section{References}

1. Gold P, Freedman SO. Demonstration of tumor-specific antigens in human colonic carcinoma by immunological tolerance. J Exp Med. 1965;121:439-462. doi:10.1084/jem.121.3.439

2. Radosevich JA, Ma Y, Lee I, et al. Monoclonal antibody 44-3A6 as a probe for a novel antigen found on human lung carcinomas with glandular differentiation. Cancer Res. 1985;45:5805-5812.

3. Radosevich JA, inventor; ImmvaRx, Inc. assignee. Cancer marker protein and peptides thereof. United Sates patent US 6,166,176. 2000 Dec 26. Available from: http://patft.uspto.gov/netacgi/nph-Parser? Sect $1=$ PTO $2 \&$ Sect $2=$ HITOFF $\& \mathrm{p}=1 \& \mathrm{u}=\% 2$ Fnetahtm $1 \% 2 \mathrm{FPTO} \%$ 2Fsearch-bool.html\&r=1\&f=G\&l=50\&co1=AND\&d=PTXT\&s1= Radosevich.INNM.\&s2=6,166,176.PN.\&OS=IN/Radosevich+AND $+\mathrm{PN} / 6,166,176 \& \mathrm{RS}=\mathrm{IN} /$ Radosevich+AND+PN/6,166,176. $\quad$ Accessed September 17, 2019.
4. Radosevich JA, Noguchi M, Rosen ST, Shimosato Y. Immunohistochemical analysis of human adenocarcinomas of the lung using the monoclonal antibody 44-3A6. Tumor Biol. 1990;11:181-188. doi:10.1159/000217653

5. Ordóñez NG. The value of antibodies 44-3A6, SM3, HBME-1, and thrombomodulin in differentiating epithelial pleural mesothelioma from lung adenocarcinoma. A comparative study with other commonly used antibodies. Am J Surg Pathol. 1997;21:1399-1408. doi:10.1097/00000478-199712000-00002

6. Combs SG, Radosevich JA, Ma Y, et al. Expression of the antigenic determinant recognized by the monoclonal antibody 44-3A6 on select human adenocarcinomas and normal human tissues. Tumor Biol. 1988;9:116-122. doi:10.1159/000217552

7. Duda RB, August CZ, Rosen ST, Radosevich JA. Monoclonal antibody 44-3A6 as a marker for differentiation of breast cancer. Tumor Biol. 1991;12:254-260. doi:10.1159/000217712

8. Combs SG, Hidvegi D, Ma Y, Rosen ST, Radosevich JA. Pleomorphic carcinoma of the pancreas with osteoclast-like giant cells expressing an epithelial-associated antigen detected by monoclonal antibody 44-3A6. Diagn Cytopath. 1988;4:316-322. doi:10.1002/dc.2840040409

9. Cajulis RS, Szumel R, Frias-Hidvegi D, Combs SG, Radosevich JA. Monoclonal antibody 44-3A6 as an adjunct in cytodiagnosis of adenocarcinomas in body fluids. Diagn Cytopath. 1993;9:179-183. doi:10.1002/dc.2840090214

10. Radosevich JA, Combs SG, Rosen ST. Expression of the epitope recognized by the monoclonal antibody 44-3A6 during human fetal development. Tumor Biol. 1991;12:321-329. doi:10.1159/000217733

11. Babich M, Radosevich JA. Humanized antibodies against labyrinthin, a specific pan-adenocarcinoma target. FASEB J. 2006;20(5). Available from: https://www.fasebj.org/doi/10.1096/fasebj.20.5. LB109-a. Accessed September 17, 2019.

12. Alexander B What's key to the next cancer breakthrough? The answer may lie in pan-tumor biomarkers. STAT News.com. 2019 May 22. Available from: https://www.statnews.com/sponsor/2019/05/22/whatskey-to-the-next-cancer-breakthrough. Accessed September 17, 2019.

13. Okamura R, Boichard A, Kato S, et al. Analysis of NTRK alterations in pan-cancer adult and pediatric malignancies: implications for NTRK-targeted therapeutics. JCO Precis Oncol. 2018;2:1-20. doi:10.1200/PO.17.00191

14. Schrock AB, Ouyang C, Sandhu J, et al. Tumor mutational burden is predictive of response to immune checkpoint inhibitors in MSI-high metastatic colorectal cancer. Ann Oncol. 2019;30(7):1096-1103. doi:10.1093/annonc/mdz134

15. Yang H, Song K, Xue T, et al. The distribution and expression profiles of human aspartyl/asparaginyl beta-hydroxylase in tumor cell lines and human tissues. Oncol Rep. 2010;24:1257-1264. doi:10.3892/or_00000980

16. Garg H, Suri P, Gupta JC, Talwar GP, Dubey S. Survivin: a unique target for tumor therapy. Cancer Cell Int. 2016;16(1):49. doi:10.1186/ s12935-016-0326-1

17. Shojaei F, Yazdani-Nafch F, Banitalebi-Dehkordi M, Chehelgerdi M, Khorramian-Ghahfarokhi M. Trace of survivin in cancer. Eur J Cancer Prev. 2019;28(4):365-372. doi:10.1097/CEJ.0000000000000453 


\section{Publish your work in this journal}

OncoTargets and Therapy is an international, peer-reviewed, open access journal focusing on the pathological basis of all cancers, potential targets for therapy and treatment protocols employed to improve the management of cancer patients. The journal also focuses on the impact of management programs and new therapeutic agents and protocols on patient perspectives such as quality of life, adherence and satisfaction. The manuscript management system is completely online and includes a very quick and fair peer-review system, which is all easy to use. Visit http://www.dovepress.com/ testimonials.php to read real quotes from published authors. 